\title{
WHEN IS A PRINCIPAL CHARGED WITH AN AGENT'S KNOWLEDGE?
}

\author{
DEBORAH A. DEMOTT*
}

\section{INTRODUCTION}

Within the common law of agency, rules of imputation govern when a principal is deemed to know facts that are known by an agent. The common law defines agency as a consensual and fiduciary relationship in which one person's actions have power to affect the legal relations of another person; an agent acts on behalf of a principal and is subject to the principal's control. ${ }^{1}$ Imputation comes into play in determining a principal's legal rights and obligations as between the principal and third parties with whom the agent deals on the principal's behalf, when knowing a fact is relevant to legal relations. Imputation has been characterized as a disorderly doctrine that is difficult to rationalize and to justify or explain in any satisfying or comprehensive way. ${ }^{2}$ The doctrine presents challenges because it applies broadly and to widely ranging circumstances. Imputation also requires a counter-intuitive willingness to assume that one person's knowledge, without more, is known by another person. These difficulties are worth confronting, though, because imputation is central to the bases on which agency ascribes responsibility for one person's actions to another person and thus to agency doctrine as a whole.

Copyright (c) 2003 by Deborah A. DeMott.

* David F. Cavers Professor of Law, Duke University. Since late 1995, I have been the Reporter for Restatement Third, Agency. Statements made in this essay do not represent the position of the American Law Institute, under whose sponsorship Restatements are prepared. For helpful comments on an earlier draft of this essay, I thank Francis Reynolds, Martin Stone, and Peter Watts.

My scholarly work was greatly enriched over the years by my colleague Professor Herbert Bernstein, who was unmatched in the enthusiasm and insight he brought to conversations about the law (and much else).

1. Formally defined, "[a]gency is the fiduciary relationship that arises when one person (a 'principal') manifests assent to another person (an 'agent') that the agent shall act on the principal's behalf and subject to the principal's control, and the agent manifests assent or otherwise consents so to act." RESTATEMENT (THIRD) OF AGENCY § 1.01 (Tentative Draft No. 2, 2001).

2. See F.M.B. REYNOLDS, BowsTEAD AND REYNOLDS ON AGENCY 441 (17th ed. 2001). 
This essay begins by exploring the basics of how imputation doctrine operates, including the circumstances under which an agent is treated as knowing a fact. Although the primary focus is on cases from the United States, contrasting English cases are discussed at points. The essay next evaluates competing justifications for imputation. It argues that the traditional justifications for imputation, though helpful, are incomplete and ultimately unsatisfactory because they fail to account for well-settled aspects of imputation doctrine and its consequences. The essay then advances alternate justifications that achieve a closer correspondence between imputation and other agency doctrines. In particular, imputation recognizes that the relationship between principal and agent may create incentives for an agent to be reticent in transmitting information to the principal when the agent believes the principal may prefer not to know the information.

Imputation may seem a counterintuitive or primitive legal doctrine or practice. It's natural to think that what one person knows becomes known by others only as a result of some intermediate process of communication or learning. Likewise, we don't assume that what one person knows, another person also knows simply because of the relationship between them. We naturally assume that the contents of a person's mind are just that-tied to or embedded in that person's conscious and unconscious mental states and not automatically within the mind of another person. Thus, imputation may seem to require some suspension of ordinary assumptions about how human cognition in fact works.

Imputing one person's knowledge to another could be characterized as a quintessential legal fiction. It is a representative instance in which the law for some reason deems something to be true that is not in another respect. ${ }^{3}$ Moreover, basic aspects of the common law of agency could be characterized as fiction piled upon fiction. For example, like much else in the law, agency includes within its cast of characters actors who are not natural persons, such as nation-states and corporations. Treating nations and corporations as legally consequential persons necessitates doctrines-like imputation and other agencylaw doctrines-that explain how such persons may take action in the

3. On legal fictions generally, see LON L. FULLER, LEGAL FICTIONS (1967); Note, Lessons from Abroad: Mathematical, Poetic, and Literary Fictions in the Law, 115 HARV. L. Rev. 2228 (2002). 
physical world with legal consequences. ${ }^{4}$ Thus, one fiction-corporate personality-may necessitate another fiction-imputation.

As it happens, many legal fictions are unproblematic because they are not deceptive. This is because some consequences of legal doctrine, like corporate personality, may have originated as fictions but now fool no one because their operation is so widely known. ${ }^{5}$ Imputation, likewise, is not likely to fool people into thinking that a principal in fact knows what an agent knows because the doctrine is so well-established that people recognize it for what it is, a mechanism with which the law ascribes responsibility.

\section{TWO BASIC ILLUSTRATIONS}

As a general matter, imputation charges a principal with the legal consequences of knowledge of a fact known by an agent when knowledge of the fact is material to the agent's duties to the principal and to the principal's legal relations with third parties. ${ }^{6}$ The doctrine is applicable in a diverse range of circumstances, given the variety of situations in which knowledge of a fact is relevant to a person's legal rights and duties. For example, knowing a fact may make an actor's conduct

4. Ascribing legal personality to corporations and other legal entities is problematic if an individual human being is treated as the paradigmatic legal subject, as opposed to one instance of a legal subject. See Nicola Lacey, 'Philosophical Foundations of the Common Law': Social not Metaphysical, in OXFORD ESSAYS IN JURISPRUDENCE 17, 25 (4th ser., Jeremy Horder ed., 2000). Professor Lacey suggests recognizing that, whether a person is an individual or a corporation, "legal personality is not straightforwardly descriptive: rather, it makes reference to the conditions under which it is true to say that some social phenomenon-human, corporate, or other-may be held liable in law." Id. at 26. Consistent with this insight, not all human beings have capacity to do all legally consequential acts. For example, minors lack capacity in many instances to enter into binding contracts. Within agency, capacity to do an act through an agent is a function of the principal's capacity. See RESTATEMENT (THIRD) OF AGENCY § 3.04(1) (Tentative Draft No. 2, 2001) (stating that an agent may act when the principal "would have capacity if acting in person at the time the agent takes action"). A person's power to act as an agent may exceed the person's capacity to be bound as a principal. See id. $\S 3.05 \mathrm{cmt}$. b ("The capacity to do a legally consequential act by means of an agent is coextensive with the principal's capacity to do the act in person.").

5. See Fuller supra note 3, at 19:

Probably the maxim "qui facit per alium, facit per se" was originally a fiction because it was understood as an invitation to the reader to pretend that the act in question had actually been done by the principal in person. But the statement has been so often repeated that it now conveys its meaning (that the principal is legally bound by the acts of the agent) directly; the pretense that formerly intervened between the statement and this meaning has been dropped out as a superfluous and wasteful intellectual operation. The death of a fiction may indeed be characterized as a result of the operation of the law of economy in the field of mental processes. (emphasis added).

6. See Restatement (Third) of Agency $\S 5.03$ (Tentative Draft No. 3, 2002) (imputing to the principal material facts "an agent knows or has reason to know"). 
tortious or may establish a defense to liability. A person may own property subject to another person's interest in the property if the owner acquires the property with knowledge of the other person's interest. Moreover, having knowledge of a fact may determine whether a person has asserted legal rights in a timely fashion.

Before examining exceptions and variations, it is helpful to see how the basic principle of imputation applies to two concrete and typical sets of facts. First, suppose Isabella, an art collector, wishes to acquire property on which to build a museum to house her collection. She retains Bernard as her agent for this purpose. Bernard locates a suitable property and negotiates a purchase price and other terms with Henry, the owner of the property. Prior to closing, Bernard learns that the property is subject to an unrecorded lien in favor of Maisie. Bernard does not tell Isabella about Maisie's lien and purchases the property for Isabella. If Isabella herself knew about Maisie's lien, she would hold the property subject to it. If Bernard's knowledge of the lien is imputed to Isabella, she holds the property subject to Maisie's lien as if she had actual personal knowledge of it. ${ }^{7}$

Notice the practical consequences of imputing Bernard's knowledge to Isabella. Imputation determines the parties against whom a third party may assert claims, as well as the remedies available. Imputation gives Maisie a claim against property that Isabella owns as a consequence of her transaction with Henry. Unless Bernard's knowledge is imputed to Isabella, Maisie is left without a claim against the property; indeed, unless Isabella is charged with Bernard's knowledge, Maisie may be left with no remedy at all. Maisie was not a party to the transaction between Isabella and Henry, and she has no relationship with Bernard on the basis of which she might establish that Bernard owed her a duty to protect her interests. Leaving Maisie in a remediless predicament could be justified, of course, on the basis that her lien was unrecorded. Relying on that justification to leave Maisie without a remedy would leave the nagging question why Isabella would acquire the property subject to Maisie's lien if she had personal knowledge of it. If the fact that the lien is unrecorded does not vitiate

7. For a recent example, see Gregg v. Cloney (In re Marriage of James \& Dana Cloney), 110 Cal. Rptr. 2d 615, 623 (Cal. Ct. App. 2001) (holding that an agent's knowledge of specific information material to his duties "that could have a substantial adverse effect on the principal" will be imputed to the principal; thus, the court imputed the agent's knowledge of a vendor's use of alternate names to the purchaser of a property). See generally RESTATEMENT (SECOND) OF AGENCY $§ 274$ (1958) ("The knowledge of an agent who acquires property for his principal affects the interests of his principal ... to the same extent as if the principal had acquired it with the same knowledge.”). 
its effect if Isabella personally knows about it, it's hard to see why the same fact is relevant if only Bernard knows about Maisie's lien.

Second, and redeploying some of the same parties, suppose Isabella retains Bernard as her agent to deal in paintings. Bernard sells a painting owned by Isabella to Junius, representing that it is a Vermeer. Bernard knows that this statement is not true because he knows that the painting is a skillfully-executed nineteenth-century forgery. Bernard does not share this information with Isabella or with Junius, both of whom believe the painting to be a Vermeer. If Bernard has defrauded Junius, it is because he has made a false statement of a material fact, knowing it to be false, and Junius has acted reasonably in relying on it. If Bernard's knowledge of the falsity of his statement is imputed to Isabella, she, like Bernard, is subject to liability to Junius for fraud. ${ }^{8}$

In this illustration as in the first, imputation is relevant to determining the parties against whom a third party may have claims and the remedies that may be available. The actor's state of mind is an element of the tort of fraud; imputing Bernard's knowledge of the falsity of his statement to Isabella underlies Isabella's vicarious liability for Bernard's tortious misstatement to Junius. However, in contrast to the first illustration, Junius is not without a remedy if Bernard's knowledge is not imputed to Isabella because Junius may sue Bernard for damages. Imputing Bernard's knowledge to Isabella adds Isabella as a prospective-and possibly more solvent—defendant. Moreover, against Isabella, Junius may seek rescission of the transaction by offering to return the painting in exchange for the purchase price. Rescission would not be available against Bernard because, acting only as Isabella's agent, he was not a party to the transaction and does not possess the sale proceeds.' Alternatively, suppose Bernard did not

8. See, e.g., Dyke v. Peck, 719 N.Y.S.2d 391, 394 (N.Y. App. Div. 2001) (imputing to a seller a material misrepresentation made by his agent to a buyer of real estate and holding that the buyer's reliance was not reasonable under the circumstances).

9. This point has ramifications that are beyond the scope of this essay. Consider the structure of agency relationships in typical sales transactions in residential real estate. If a propertyowner consents, the agent with whom the property is listed may offer other real-estate brokers a share of any sales commission if a prospect to whom they show the property purchases it. The common-law rule in most states characterizes a "showing broker" as the seller's subagent, that is, an agent to whom the listing agent delegated performance. See Stortroen v. Beneficial Fin. Co., 736 P.2d 391, 396 (Colo. 1987) (citing cases). If the showing broker defrauds the purchaser, remedies available to the purchaser include rescission. Id. (quoting Molly Moore Romero, Theories of Real Estate Broker Liability: Arizona's Emerging Malpractice Doctrine, 20 ARIZ. L. REV. 767, 773 n.33 (1978)). On the other hand, if a showing broker is characterized as the purchaser's agent, rescission will not be an available remedy if the showing broker defrauds the 
know that his representation about the painting was false and that he made the representation negligently or even innocently. Bernard's representation, attributed to Isabella as his principal, provides Junius with a basis on which to seek damages from Isabella for his loss or to seek rescission of the purchase..$^{10}$

Imputation also lurks in the legal background if we focus solely on the contract-law analysis of this transaction and its consequences. Junius might argue that Bernard's statement about the painting constituted an express warranty because it was an affirmation of fact relating to the painting that became part of the bargain between Isabella and Junius. ${ }^{11}$ The fact that the painting is a forgery would breach the warranty and subject Isabella to liability to Junius for breach of contract. Bernard would not be subject to liability because he was not a party to the contract. ${ }^{12}$ Junius's remedies for breach of warranty do not depend on whether he can show that Bernard knew that his statement about the painting was false when he made it, which may make the breach of warranty theory attractive. If Junius takes this route, his claim for breach of warranty would reach only Isabella and the remedies for breach of warranty would not include exemplary or punitive damages that may be available in an action for fraud. ${ }^{13}$

purchaser. See id. (holding that where "there is no agency relationship between the seller and the selling broker, but [there is an] agency relationship ... between the buyer and the selling broker, th[e] remedy of rescission is no longer available to the buyer because the ratification doctrine would not be applicable" (quoting Romero, supra at 773 n.33)).

10. On liability for negligent and innocent misrepresentations, see RESTATEMENT (SECOND) OF TORTS $\S 552 \mathrm{~B}, 552 \mathrm{C}(1976)$.

11. Under U.C.C. $\$ 2-313$ (a) (2002), a seller of goods creates an express warranty through "[a]ny affirmation of fact or promise made by the seller to the buyer which relates to the goods and becomes part of the basis of the bargain ...." The express warranty so created is that "the goods shall conform to the affirmation or promise." Id. An express warranty may be created although the seller does not use such words as "warrant" or "guarantee"; but an affirmation that goes only to "the value of the goods or a statement purporting to be merely the seller's opinion or commendation of the goods does not create a warranty." Id. § 2-313(2).

12. See Restatement (SECOND) OF AGENCY $\S 320$ (stating that a person who makes or purports to make a contract on behalf of a disclosed principal is not a party to the contract). An agent for a disclosed principal is not liable for nonperformance of a contract that the agent makes on behalf of the principal. Id. $\S 328$.

13. Depending on when Junius learns the truth, he may reject the painting when delivery is tendered, see U.C.C. § 2-601, if he can do so within a "reasonable time" following tender of actual delivery, id. $\$ 2-602(1)$. A buyer may rightfully reject goods that fail in any respect to conform to the contract. Id. §2-601. If Junius learns the truth after he has accepted the painting, he may revoke his acceptance "within a reasonable time after [he] discovers or should have discovered the ground for it and before any substantial change in condition of the goods which is not caused by their own defects." Id. $\S 2-608(2)$. A buyer may revoke acceptance when a nonconformity substantially impairs the value of goods to the buyer. Id. § 2-608(1). If a buyer rightfully 
Isabella might resist Junius's argument that Bernard's statement constituted a warranty on the basis that she did not intend to make any warranty about the painting. Additionally, she might argue that Bernard's statement exceeded his authority to act on her behalf because she authorized him only to sell the painting, not to make factual affirmations about it on her behalf. Isabella's line of defense is likely to fail. If Bernard had authority to sell the painting for Isabella, she is charged with the legal consequences of representations that Bernard makes that are incidental to the sale, so long as Junius had no reason to doubt the truth of Bernard's statement. ${ }^{14}$ Likewise, it is not a defense to Isabella if she can establish that, while she authorized Bernard to make factual affirmations about the painting, his authority encompassed only true affirmations. ${ }^{15}$ Having deployed Bernard as her representative for purposes of selling the painting, Isabella becomes subject to the legal consequences of the means Bernard uses.

The basic illustrations both involve typical transactions and legal consequences stemming from imputation. Additionally, both involve a kind of fact that is typical in cases involving imputation. This is a fact, known by an agent, that most principals would prefer not to be true or, if true, a fact that many principals would prefer not to know. Isabella would prefer that it not be so that Maisie holds an unrecorded lien against property that Isabella purchases and, if it were so that Maisie holds such a lien, Isabella would prefer not to know about the lien. Less typically, imputation may benefit a principal. For example, material facts known to an agent may establish that the agent acted reasonably when the law requires reasonable action. Imputing notice of those facts to the principal benefits the principal. ${ }^{16}$ Most im-

rejects goods or revokes acceptance of the goods, and the goods are unique, the buyer's remedies begin with the right to recover "so much of the price as has been paid" plus damages for incidental and consequential loss. Id. $\S \S 2-711(1), 2-712(2)$. If Junius does not reject the painting or revoke acceptance, his remedy is damages for the difference between the value of the painting as warranted and the value of the painting he accepted, plus any incidental or consequential damages. Id. §2-714(2).

14. See RESTATEMENT (SECOND) OF AGENCY $§ 162$ (stating that a principal's accountability under this section does not extend to statements an agent makes about his own authority).

15. See id. $\S 162 \mathrm{cmt}$. b:

The authorization of the agent to make true statements concerning the subject matter of a contract does not authorize him to make those which he knows or should know are untrue. If the agent is authorized to make representations concerning a certain matter, however, the principal is responsible for them if untrue statements are made.

16. See Restatement (THIRD) OF AGENCY $§ 5.03 \mathrm{cmt}$. c(ii) (Tentative Draft No. 4, 2003) (noting that such imputed reasonable behavior affects the principal's underlying tort liability). Imputation may also have the consequence of creating a defense against a fraud claim. Suppose 
putation cases, though, involve facts that will not be beneficial to the principal's legal position if the principal is charged with an agent's knowledge of them.

The basic illustrations are also typical because the facts known to an agent are relevant to the values to be exchanged in the two transactions. Often the facts that an agent knows are relevant to the price and terms around which parties structure a transaction, or, more precisely, would structure the transaction if the facts were known to them. In the second illustration, Junius will pay less for the painting if he knows that it is a well-executed forgery and he will pay more if he believes it to be a Vermeer. If Isabella is shielded from the legal consequences of Bernard's knowledge, her dealings with Junius will not reflect material facts relevant to the painting's value and their transaction will be mispriced. Similarly, in the first illustration, Maisie's lien is relevant to the price that a buyer will pay for Henry's property and to the terms that an informed buyer will demand.

Although Bernard did not do so, an agent may disclose the existence of bad facts like these to the principal. An agent ordinarily has a duty to disclose material facts to the principal on whose behalf the agent acts. ${ }^{17}$ Other ramifications of the duty of disclosure are discussed below, but notice as an initial matter that a basic consequence of imputation is to charge a principal with notice of facts whether or not an agent has fulfilled the agent's duty of disclosure or has breached the duty.

Why might Bernard breach his duty of disclosure? An agent's breach of duty subjects the agent to liability to the principal for loss the principal suffers as a result of the agent's breach. ${ }^{18}$ An agent may breach the duty of disclosure because the agent does not understand the significance of the facts in question. However, as the illustrations

\footnotetext{
that Bernard acts as Junius's agent, that Bernard knows that the purported Vermeer is a forgery, and that neither Isabella nor Junius know this. Imputing Bernard's knowledge to Junius would defeat Junius's claim against Isabella and would leave Bernard as the sole defendant that Junius may pursue. See, e.g., Jay Group, Inc. v. Glasgow, 534 S.E.2d 233, $236-37$ (N.C. App.), appeal denied, 546 S.E.2d 100, 100 (N.C. 2000) (imputing to an acquiring corporation its officers' knowledge that trademarks of the acquired corporation could not be registered and rejecting the acquiring corporation's fraud claim based on failure to disclose).

17. See Restatement (SECOND) OF AGENCY § 381:

Unless otherwise agreed, an agent is subject to a duty to use reasonable efforts to give his principal information which is relevant to affairs entrusted to him and which, as the agent has notice, the principal would desire to have and which can be communicated without violating a superior duty to a third person.

18. See id. $\S 401$ (subjecting an agent to liability "for loss caused to the principal by any breach of duty").
} 
are structured, this is not likely to be a plausible explanation for Bernard's failure to make disclosure to Isabella. Bernard might fail to make disclosure to Isabella when he fears that Isabella will not proceed with the transactions with Henry and Junius if she knows what Bernard knows. If Bernard's claim to compensation depends on completing a transaction, his desire to be paid may supersede his compliance with duties he owes his principal, Isabella, as well as duties he owes to other parties, including Junius, the purchaser of the painting. Bernard may place a higher value on the prospect of immediate payment for his services than he does on the more remote prospect that Isabella or Junius will sue him. He would be especially likely to do so if he believes that Junius and Isabella (and Maisie for that matter) are unlikely to discover that they have been injured or that they are unlikely to assert their rights promptly or effectively.

Imputation also recognizes the possibility that a principal might have instructed an agent not to disclose bad facts to the principal by explicitly or implicitly making it clear to the agent that the principal would prefer not to know. Thus, if Bernard reasonably understands that Isabella wishes not to know about forgeries and unrecorded liens, his failure to tell her may not breach his duty to her. Isabella might indicate that she prefers not to be burdened with this knowledge if she, too, places a high value on the immediate benefits that she believes will flow from the transaction relative to the prospect that Junius and Maisie will discover their injuries promptly. The likelihood that some agents act as they do because they reasonably understand that the principal so wishes helps explain the infrequency with which principals bring actions against agents when what appears to be a breach of duty by the agent has resulted in loss for the principal. ${ }^{19}$ To be sure, other factors also help explain the infrequency with which principals seek indemnity from agents, but the implicit terms of

19. In particular, when an agent is an employee and the loss is a consequence of inadvertent error, a principal may be concerned about the impact on work-force morale. One line of attack on an employer's right of indemnity against an employee is that no employee expressly or impliedly undertakes to be infallible. See Romford Ice \& Cold Storage Co. v. Lister, [1956] 2 Q.B. 180, 187 (Eng. C.A.) (Denning, L.J., dissenting) ("No man, if asked, would give a warranty to his employer that he would at all times, without exception, come up to the standard of the reasonable man of the law who, so far as I know, when he is driving, never makes a slip or a mistake."). In the same case, the House of Lords unanimously held that an employee owes a contractual duty of care to the employer and that breach of the duty gives rise to a claim for damages by the employer. See Lister v. Romford Ice \& Cold Storage Co., 1957 A.C. 555, 556 (1956) (holding a truck driver liable to his employer for damages caused by breaching his duty of care). For a critique of the implied contract theory, see generally Roscoe T. Steffen, The Employer's "Indemnity” Action, 25 U. CHI. L. REV. 465 (1958). 
understanding as between agent and principal may inhibit the principal's willingness to move against the agent.

However, from the standpoint of Maisie and Junius, it is not a source of comfort that Isabella and Bernard may have reached a private understanding that restricts what Bernard tells Isabella. Charging Isabella with the legal consequences of Bernard's knowledge does not require that Maisie or Junius prove the actual facts of any private understanding that Isabella and Bernard may have had. Imputation, that is, does not turn on whether a third party can establish explicit collusion between a principal and an agent or an implicit understanding that the agent will shield the principal from knowledge of bad facts. It would often be difficult for a third party to establish the facts of the operative understanding between a principal and an agent, especially when neither has reason to betray the other. It is also possible that an agent may withhold information from a principal because the agent misunderstands the principal's wishes. Imputation makes it unnecessary for a third party to establish that the principal directed or authorized the agent to withhold material information.

\section{WHEN DOES AN AGENT KNOW A FACT?}

It is possible to draw many shadings of degree within the concept of knowledge. ${ }^{20}$ The most basic distinction for our present purposes is between (1) a fact that a person knows or has reason to know on the basis of an inference reasonably to be drawn from facts known; and (2) a fact that a person should know because the person would know the fact if the person discharged a duty owed to another person. To illustrate this distinction, consider a variation on the first illustration. Suppose that Henry, who owns the property that Isabella purchases, retains Dora to represent him in selling the property. As it happens, Dora resides in the same neighborhood and knows that, periodically, high winds whip through it and damage structures. Even if Dora claims to lack actual knowledge that Henry's property is also suscep-

20. An English court stated five possibilities:

(i) [a]ctual knowledge; (ii) wilfully shutting one's eyes to the obvious; (iii) wilfully and recklessly failing to make such inquiries as an honest and reasonable man would make; (iv) knowledge of circumstances which would indicate the facts to an honest and reasonable man; (v) knowledge of circumstances which would put an honest and reasonable man on inquiry.

Baden v. Société Générale, [1993] 1 W.L.R. 509, 575-76. 
tible to wind damage, Dora has reason to know this fact. ${ }^{21}$ Likewise, suppose Dora inspects a building on Henry's property and notices small piles of sawdust around the building's foundation. Dora knows-either as a consequence of her training as a real estate agent or though her experience as a property owner or otherwise- that the sawdust is indicative of termite infestation. However, not wanting to delay the transaction, Dora does not check further. Dora has reason to know of the strong likelihood that the building is to some degree infested by termites because she has "received sufficient information to awaken inquiry." 22

In both cases, Henry is charged with reason to know the facts that Dora has reason to know, even though Dora claims that she lacked actual knowledge of any termite infestation or adverse wind conditions that afflicted Henry's property. As a consequence, Henry may be subject to liability to Isabella, who purchased Henry's property. Restricting imputation to facts of which an agent has actual knowledge would make it attractive for agents to ignore or turn a blind eye to facts that the agent would prefer not to know, often because the agent believes that the principal would prefer not to know the facts. A phrase in English cases, "blind-eye knowledge," 23 nicely captures scenarios in which a person knows enough of the facts to know that further inquiry may lead conclusively to bad news.

In contrast, suppose Dora makes no investigation at all of the condition of Henry's property. Dora thus lacks knowledge of the indicia of termite infestation. This may be a fact that Dora "should know" because she has a duty to Henry to inspect the property. Dora may also have a duty, as may Henry, that is owed to anyone who pur-

21. For comparable facts, see Carter v. Gugliuzzi, 716 A.2d 17, 20 (Vt. 1998) (imputing to a brokerage house its agent's knowledge of a property's susceptibility to "frequent and severe winds").

22. Southport Little League v. Vaughn, 734 N.E.2d 261, 275 (Ind. Ct. App. 2000) (citing Travelers Ins. Co. v. Eviston, 37 N.E.2d 310, 316 (Ind. App. 1941)).

23. In the English cases, "blind-eye knowledge" refers to situations under policies of maritime insurance in which an insured or its agent suspects the existence of facts that mean that a ship is unseaworthy but consciously refrains from further inquiry. See The Eurysthenes, 1977 Q.B. 49, 68 (1976) (Denning, L.J.) (stating that blind-eye knowledge requires proof "that a reasonably prudent owner in [the owner's] place would have known the facts and have realized that the ship was not reasonably fit to be sent to sea"). To turn a blind eye to a situation does not always imply conduct that is morally dubious. Consider Horatio Nelson's naval victory over the French at the battle of Copenhagen in 1801. Lord Nelson's superiors hoisted signal flags directing him to retreat. However, "Nelson ... made a deliberate decision to place the telescope to his blind eye in order to avoid seeing what he knew he would see if he placed it to his good eye." Manifest Shipping Co. v. Uni-Polaris Ins. Co., [2001] 2 W.L.R. 170, 208 (H.L.). 
chases the property, to inspect the property and disclose the findings of the inspection. Dora's failure to inspect the property thus may breach a duty she owes to Isabella, the purchaser of the property, and may also breach a duty she owes to Henry. Like a cascading line of dominoes, Dora's breach of duty will cause Henry to breach any duty he owes to Isabella to inspect the property prior to selling it if Henry relies solely on Dora to do the inspection. Henry may thus be subject to liability to Isabella.

This result does not turn on imputation, in this instance imputation of knowledge of a fact that Dora neither knows nor has reason to know but "should know" to fulfill her duty. Henry would be subject to liability to Isabella if Henry owes Isabella a duty and Henry has delegated performance of the duty to Dora, who did not fulfill the duty. ${ }^{24}$

An additional question is whether an agent should be deemed to know what the principal knows-whether imputation, in other words, operates only unidirectionally, upward from agent to principal, or downward as well, from principal to agent. Suppose Isabella knows that the painting she sells to Junius as a Vermeer is a nineteenthcentury forgery but also knows that Bernard (and Junius) do not know this and believe the painting to be genuine. Bernard sells the painting on Isabella's behalf to Junius. Is Bernard subject to liability to Junius? Recall that when it is Bernard who knows that the painting is a forgery, Isabella is charged with Bernard's knowledge and is subject to liability to Junius for fraud, as is Bernard. If Isabella's knowledge were imputed downward to Bernard, Bernard would be subject to liability to Junius.

Cases with facts comparable to this hypothetical do not impute a principal's knowledge downward to the agent. ${ }^{25}$ This limit on imputation protects an agent from the legal consequences of facts that only the principal knows or has reason to know. Otherwise, an agent would risk liability whenever the principal, for whatever reason, has more information than does the agent about a transaction executed

\footnotetext{
24. See Restatement (SECOND) OF AGENCY $\$ 277 \mathrm{cmt}$. b (1958):

The principal is affected by information which the agent should have acquired if the principal has a contractual or other duty to third persons with respect to a matter entrusted to the agent. In such cases the principal is subject to liability for failing to act in the light of information which he should have acquired if he himself had done the work.

25. See, e.g., Ago v. Begg, Inc., 705 F. Supp. 613, 617-18 (D.D.C. 1988) ("[T]he law of agency ... sensibly does not hold agents responsible for knowledge known only by the principal." (citation omitted)), aff'd, 911 F.2d 819 (D.C. Cir. 1990).
} 
by the agent. However, does the unidimensional quality of imputation also provide a defense to the principal? May Isabella argue that she is not subject to liability to Junius for fraud because her agent in the transaction, Bernard, did not know that his statement to Junius was false? If so, principals would systematically find it attractive to shelter their agents from facts most likely to be material to the transactions in which any particular agent may be engaged. The cases foreclose this possibility. Isabella may be subject to liability to Junius if she withholds material information from Bernard, knowing that he will misstate material facts to Junius or another third party as a result. ${ }^{26}$ However, Isabella's liability does not turn on imputing her knowledge to Bernard or imputing notice to her of a fact that Bernard does not know. The basis for Isabella's liability is that she has used Bernard, an innocent instrumentality, to mislead Junius. ${ }^{27}$ Isabella's use of Bernard, who says what Isabella predicts he will say to Junius but does not know that what he says is false, is comparable to Isabella presenting Junius with a published catalog that Isabella knows attributes the painting to Vermeer, when the author of the catalog, like Bernard, did not know the true story.

26. See Essex v. Getty Oil Co., 661 S.W.2d 544, 550-51 (Mo. Ct. App. 1983) ("The fact that the person used as an agent to convey the representation is innocent does not relieve the party charged with fraud."); RESTATEMENT (SECOND) OF AGENCY § 256 (assigning liability to a principal for failing to reveal material facts to an agent who, "because of his justifiable ignorance ... makes a material misstatement of facts").

27. Some authorities treat downward imputation as a device to establish liability on the part of the principal, not the agent. For an early example, see JOSEPH STORY, COMMENTARIES ON THE LAW OF AGENCY AS A BRANCH OF COMMERCIAL AND MARITIME JURISPRUDENCE, WITH OCCASIONAL ILLUSTRATIONS FROM THE CIVIL AND FOREIGN LAW $§ 140 d$ (N. St. John Green ed., 8th ed. 1874):

notice of facts to the principal is ordinarily notice thereof to the agent; for it is the duty of the principal to communicate to his agent notice of the facts which come to his knowledge, touching the matter of the agency; and if the principal suffers any loss or injury by want of such notice, he suffers by his own fault; and if the other party is injured thereby, he ought to have correspondent redress. The law, therefore, imputes the knowledge of the principal to be the knowledge of the agent ....

(footnote omitted).

In contemporary contexts defined by a regulatory statute, some courts have imputed notice of facts known by a principal downward to an agent when the principal has a duty to transmit all material facts to the agent and the statute's regulatory purpose would be undermined by limited disclosure to agents. This reasoning has been applied to the portion of the federal Fair Debt Collection Practices Act which prohibits communication by a debt collector to a consumer if the collector knows the consumer is represented by a lawyer. 15 U.S.C. $\$ 1692$ c(a)(2) (2000). See Powers v. Prof'l Credit Serv., Inc., 107 F. Supp. 2d 166, 169 (N.D.N.Y. 2000) ("Knowledge can be imputed to the debt collector when the creditor [principal] has such knowledge and fails to convey it to its agent, the debt collector, at the time it seeks collection."). 


\section{THE PROVENANCE OF AGENTS' KNOWLEDGE}

Agents, like all persons, acquire knowledge through many different means and in many settings. In particular, an agent may learn a fact when the agent is acting on behalf of another principal or is acting solely on the agent's own behalf. The question is whether knowledge that an agent acquires apart from an agency relationship should be imputed to the principal. For example, suppose Bernard knows about Maisie's lien on Henry's property because he learned about it in an earlier transaction in which he represented another principal. If he remembers the lien when he acquires the property for Isabella, is his knowledge imputed to Isabella? She might well argue that Bernard, although acting as her agent in acquiring Henry's property, was not acting as her agent when he learned about Maisie's lien. Or suppose Bernard learns about Maisie's lien, or learns that the purported Vermeer is a forgery, at a dinner party with friends. Should Isabella be charged with knowledge Bernard acquires when he is not working for any principal?

On this point, English cases give weight to the provenance of an agent's knowledge. ${ }^{28}$ In the most memorable case, Société Général v. Tramways Union Co., Ltd., a company's secretary learned that shares in the company were subject to an equitable charge when, on the day of a relative's funeral, he learned of the charge at a family session where the solicitor for the relative's executor read out the decedent's will and an agreement creating the charge to those assembled. ${ }^{29}$ The court held that notice of the charge should not be imputed to the company because "[t]he secretary was in no way representing the company at the funeral; no notice was given to him as the agent of the company, nor did he acquire any knowledge of the defendant's security whilst transacting the company's business, or in any way for or on behalf of the company.", ${ }^{30}$

In contrast, for the most part, U.S. cases focus on whether an agent's knowledge is material to the agent's duties to the principal but not on the circumstances under which the agent acquired the information, unless the agent learned the knowledge under circumstances creating a duty of confidentiality to another party. ${ }^{31}$ For example, a

28. See REYNOLDS, supra note 2, at 442 n. 89 (referring to several common law decisions).

29. Société Général de Paris v. Tramways Union Co., Ltd., 1884 Q.B.D. 424.

30. Id. at 450 (Lindley, L.J.).

31. See, e.g., Carter v. Gugliuzzi, 716 A.2d 17, 23 (Vt. 1998) (affirming the conclusion that the agent's knowledge was imputable to his principal "regardless of [its] source"); Daniel S. Kleinberger, Guilty Knowledge, 22 WM . MitCHELL L. REV. 953 (1996) (describing as "without 
lawyer's knowledge is not imputed to a client when communicating the knowledge would breach the lawyer's duty to another client. ${ }^{32}$ Unless an agent is bound by a duty of confidentiality to another person, and unless agent and principal have agreed otherwise, the agent's duty to the principal encompasses transmitting all material information known by the agent, regardless of its origin. ${ }^{33}$ Thus, Bernard's duty to Isabella requires disclosure of Maisie's lien, regardless of the circumstances under which Bernard learned about it, assuming the absence of agreement between Isabella and Bernard that he will spare her such unpleasantries. Dora has a duty to tell Henry about the perilous wind conditions that may afflict Henry's property, although Dora learned about the high winds as a consequence of living in the same neighborhood where Henry's property is situated.

Likewise, on the facts of Société Général, the duty of disclosure owed to the company by its secretary would encompass the secretary's knowledge of the charge on shares issued by the company if material to the company and the secretary's position within it. It would be beside the point that the secretary learned about the charge at a family funeral. He attended the funeral as a member of the family, and not as a representative of the company, as the court observed. However, "the mind of the agent cannot be divided into compartments." ${ }^{34}$ To be sure, agency law could so compartmentalize an

basis either in precedent or policy" a requirement that information imputed to a principal be acquired by the agent while acting within the scope of his employment); Warren A. Seavey, Notice Through an Agent, 65 U. PA. L. REV. 1, 14 (1916) ("[I]t is immaterial how or when the servant or agent acquires the information ...."). Examples to the contrary include R.B.Z. v. Warwick Dev. Co., 725 So.2d 261, 264 (Ala. 1998) (declining to impute to a principal knowledge gained by an agent prior to and outside the scope of his agency); Engen v. Mitch's Bar \& Grill, No. C7-95-78, 1995 WL 387738, at *2 (Minn. Ct. App. July 3, 1995) (holding that the party seeking to impute the agent's knowledge to the principal must establish that the agent acquired the knowledge while acting within the course and scope of his employment).

32. See Restatement (ThiRd) OF LAW GOVERNING LAWYERS $§ 28(1)$ (2000). See also Reinninger v. Prestige Fabricators, 523 S.E.2d 720, $725-26$ (N.C. Ct. App. 1999) (holding that the knowledge of a company physician, who had an ethical duty to withhold confidential communications of employee-patients, is not imputed to the employer). This limit on an agent's duty of disclosure is recognized in Kelly v. Cooper, 1993 A.C. 205, 214 (P.C. 1992) (appeal taken from Berm.) ("It cannot be sensibly suggested that an estate agent is contractually bound to disclose to any one of his principals information which is confidential to another of his principals.").

33. See Restatement (SECOND) OF AGENCY $\$ 381$ (1958):

Unless otherwise agreed, an agent is subject to a duty to use reasonable efforts to give his principal information which is relevant to affairs entrusted to him and which, as the agent has notice, the principal would desire to have and which can be communicated without violating a superior duty to a third person.

34. Id. $\$ 276 \mathrm{cmt}$. a; see also FlOYd R. MECHEM, A TREATISE ON THE LAW OF AGENCY 1391 (2d ed. 1914) (observing that the real justification for imputation is "found in the convic- 
agent's mind, but the consequence would be an implausible fiction. Principals often choose their agents on the basis of an agent's prior experiences and life apart from work. A principal may well choose an agent on the basis of the prospective agent's prior work, education, and life experience more generally, precisely because they contribute skills and knowledge that the agent may bring to bear on work for the principal. Moreover, it's likely that an agent will attempt to transmit information to the principal, regardless of its provenance, when the agent believes that the principal wishes to be told.

Thus, under U.S. law, more of an agent's knowledge is imputed to the principal than under English law, suggesting that under U.S. law an agent's duties appear to reach more pervasively into prior or private dimensions of the agent's life. However, it is open to question whether a contemporary English court, in contrast to the 1884 Société Général court, would so broadly foreclose imputation on the basis of the circumstances under which the agent acquired knowledge material to the agent's duties. Suppose the question arises as a consequence of a representation made on the principal's behalf to induce another party to enter into a transaction with it, and not, as in Société Général, when the question is the validity or priority of rights that may be asserted against property. For example, suppose that the company that issued the shares entered into a financing transaction with a third party and, as part of that transaction, warranted that it knew of no equitable liens upon its shares. If as a consequence of the statement the company is subject to liability for fraud to the third party, the breadth of Société Général's emphasis on the provenance of the agent's knowledge has been undercut.

As it happens, English cases impose liability on principals when it is very unlikely that the agent has transmitted relevant information to the principal. In a 1912 case, Lloyd v. Grace, Smith \& Co. ${ }^{35}$ the House of Lords held that a principal was liable for its agent's fraud when the agent fraudulently induced a client to convey her investment assets to him. ${ }^{36}$ Although the agent disposed of the assets for his own benefit, having engineered the entire transaction for his own gain, the principal was liable even though it neither knew about nor benefited from its agent's fraud because the fraud occurred in the

tion that it cannot be tolerated that an agent shall act in a transaction, with his mind full of material knowledge respecting it, and yet the principal be wholly unaffected by that knowledge, merely because the agent happened to acquire it before the agency began").

35. [1912] A.C. 716.

36. Id. at $735-36$ 
course of the agency. ${ }^{37}$ From the standpoint of the client who dealt with the firm through its agent, the transaction appeared to be within the scope of those the agent had authority to conduct for the firm; that the agent acted for "private motives" in contrast to the interests of the firm should not defeat the firm's liability. ${ }^{38}$ Curiously, the nature of the agent's "private motives" in Lloyd v. Grace Smith make it even less likely that the agent will reveal material information to the principal than the extramural circumstances under which the company secretary learned about the charge in Société Général.

\section{LAPSED MEMORY}

A separate dimension of knowledge is the phenomenon of forgetting; agents who are individuals may forget what they once knew. This may be due to the passage of time or because the agent acquired the knowledge in question in a superficial manner that was not conducive to long-term retention in the agent's memory. For example, suppose Bernard represents many principals in transactions comparable to the transaction through which he learned about Maisie's lien on Henry's property. Bernard's knowledge of the lien may prove ephemeral if he acquires it through one of a series of routine transactions. ${ }^{39}$ Moreover, before Bernard represents Isabella, he owes her no duty to retain facts in his memory.

Thus, a principal is not deemed to know a fact that an agent once knew but has forgotten by the time the agent acts on the principal's behalf. ${ }^{40}$ One possible difficulty with this limit on imputation is that

37. Id. at $732,736-41$.

38. Id. at 740 .

39. E.g., Constant v. Univ. of Rochester, 19 N.E. 631, 634 (N.Y. 1889). Constant involved an attorney who had acted as an agent for the University of Rochester in recording a mortgage on a property to which it had acquired title at a foreclosure sale eleven months earlier. Id. The attorney had also acted as an agent for the plaintiff, who had a mortgage on property that was not recorded at the time of the foreclosure sale. $I d$. The court found that the facts tended strongly to show that the agent had no recollection at all of the prior mortgage because the agent did an "enormous amount of business" for the plaintiff "of this same general nature," the earlier mortgage preceded the later mortgage by a significant period of time, and the earlier mortgage instrument itself was stored in the agent's office with satisfied mortgages. Id.

40. See, e.g., Chicagoland Vending, Inc. v. Parkside Ctr., Ltd., 454 S.E.2d 456, 458 (Ga. Ct. App. 1995) (holding that an agent's previously-acquired knowledge is imputed to a subsequent principal only when the agent has the information in mind in dealing for the subsequent principal, or when the agent acquired the information so recently as to warrant the assumption that the agent's mind still retained the information). A partnership is charged with the knowledge of a partner acting on a matter "acquired while a partner or then present to his mind" except in the case of a fraud on the partnership committed by or with consent of that partner. UNIF. P'SHIP ACT $\S 12$ (1914). A partner's knowledge is "effective immediately as knowledge by" the part- 
instances of claimed forgetfulness on the part of agents tend to involve knowledge that, if imputed to a principal, would have an adverse effect on the principal's legal relations with third parties. It may be difficult for a third party to show that an agent in fact remembered the information, just as it may be difficult for a third party to show that an agent duly transmitted material information to the principal. Some cases address this problem with a presumption that information an agent has recently acquired is known by the agent when the agent acts on behalf of the principal. ${ }^{41}$ Other cases explicitly allocate to the third party the burden of showing that the agent knew the information at the time of acting on the principal's behalf. ${ }^{42}$ The first approach is preferable. It can be attractive to forget "bad facts," or to claim to have forgotten them, once the consequences after-the-fact of knowledge become evident.

\section{WHEN AN AGENT ACTS ADVERSELY TO A PRINCIPAL}

A long standing-exception to imputation protects a principal from an agent's knowledge when the agent acted adversely to the principal in the transaction or other matter. However, the U.S. cases charge the principal with the adversely-acting agent's knowledge when the principal retains a benefit from the agent's actions, knowing the circumstances of the agent's conduct. The principal is also

nership except in the case of fraud on the partnership committed by or with consent of the partner. Id. § 102(f) (1997).

41. See, e.g., Pee Dee State Bank v. Prosser, 367 S.E.2d 708, 714 (S.C. Ct. App. 1988):

[As a general rule,] a principal is charged with the knowledge an agent acquired before the relationship only when the knowledge can reasonably be said to have been in the mind of the agent while acting for the principal or where he acquired it so recently as to raise the presumption he still retained it in his mind.

Overruled on other grounds by United Carolina Bank v. Caroprop, Ltd., 446 S.E.2d 415, 417 (S.C. 1994).

42. See Constant, 19 N.E. at 633 (holding that a principal would be charged with knowledge acquired by his agent in a prior transaction for another principal only "upon clear proof that the knowledge ... was present to [the agent's] mind at the very time of the transaction in question"); First Palmetto Sav. Bank v. Patel, 543 S.E.2d 241, 243 (S.C. Ct. App. 2001) (reiterating the same principle). In Constant, the agent acquired property for the principal by purchasing property at a mortgage foreclosure sale; in an earlier transaction, the agent represented the plaintiff who took an unrecorded (but prior) mortgage on the same property. 19 N.E. at 633. The agent's duty to the second principal is a basis on which the court requires an affirmative showing of knowledge at the time of the foreclosure sale; if the agent at that time knew about the earlier recorded lien, the agent acted contrary to that principal's interests in acquiring the property. Id. This argument ignores the varied reasons why the agent might remember the earlier mortgage but neglect to tell the principal. Indeed, if the agent acted with present knowledge of the earlier mortgage, the agent's acquisition of the property is contrary to the interests of the second principal only if that principal is charged with the agent's knowledge. 
charged with an adversely-acting agent's knowledge when imputation protects the interests of a third party who reasonably believed the agent to be authorized and who did not know or have reason to know that the agent acted adversely to the principal. ${ }^{43}$

This exception is tied to the underlying point that a principal is not charged with an agent's knowledge when doing so would defeat claims that the principal may assert against the agent. ${ }^{44}$ Imputation is not available as a mechanism through which an agent may defeat claims that a principal would have against the agent. Likewise, a principal is not charged with an agent's knowledge when the agent has dealt with the principal, and not with a third party on the principal's behalf. ${ }^{45}$ The "adverse interest" exception defeats imputation in a narrow range of cases involving third-party claims arising out of conduct by an agent that is so wholly antagonistic to the principal's interests that the relationship between principal and agent could be viewed as severed. ${ }^{46}$ In contrast, simply the fact that the agent acts with con-

43. See Restatement (SECOND) OF Agency $§ 282$ (1958).

44. See, e.g., E. Trading Co. v. Refco, 229 F.3d 617, 624 (7th Cir. 2000) (finding it illogical that the principal is responsible for all of the agent's actions); Nerbonne, N.V. v. Lake Bryan Int'l Props., 685 So. 2d 1029, 1032 (Fla. Dist. Ct. App. 1997) (same).

45. MECHEM, supra note 34, at 1403. The scope of the adverse interest exception has been vigorously litigated in cases involving claims made by or on behalf of corporations against providers of professional services when the provider of professional services did not detect fraud (or other breaches of duty) by the corporation's officers. If an officer's guilty knowledge is imputed to the corporation, the professional service provider may defend against a malpractice claim on the basis that the corporation did not rely on the service provider's opinion or audit. See, e.g., Cenco, Inc. v. Seidman \& Seidman, 686 F.2d 449, 453 (7th Cir. 1982) (involving a case of massive fraud within the Cenco Corporation and implicating the failure of Cenco's auditors, Seidman \& Seidman, to report such fraud). An imputation defense does not protect a service provider who is in cahoots with the officer. In many cases raising questions about imputation, the plaintiff is a corporation's receiver or trustee in bankruptcy. The common law of agency does not answer the question whether such plaintiffs are identically subject to defenses available against a corporate principal.

46. English cases appear to give wider scope to the exception. See generally Peter Watts, Imputed Knowledge in Agency Law-Excising the Fraud Exception, 117 L.Q. REV. 300 (2001). In particular, the English cases define adverse interest more broadly and do not limit the applicability of the exception when the principal retains a benefit generated by the agent's conduct. See id. at 330-31 (citing the benefit rule as an example of the "more constrained career" of the fraud exception in the United States).

In England, authority is not yet established for the distinction drawn in many cases in the United States between an agent's knowledge of a fact and whether an agent has received a notification from a third party. For support for the distinction see El Ajou v. Dollar Land Holdings plc \{1994\} 2 All E.R. 685, 702-03. REYNOLDS, supra note 2, at 438-39 ("A notification given to an agent is effective ... whether or not it is subsequently transmitted to the principal ...."). A notification is

a manifestation that is made in the form required by agreement among parties or applicable law, or in a reasonable manner in the absence of any agreement or applicable 
flicted motives or interests does not trigger the adverse-interest exception to imputation. ${ }^{47}$

It is possible to tie the scope of this exception to agency doctrine more generally by focusing on the control that a principal has in a relationship of agency. When an agent's knowledge is not imputed to a principal due to the adverse-interest exception, the agent's conduct tends to be explicable by factors outside the control and incentive structures that the principal has created. Thus, in the earlier illustrations, Bernard's knowledge of Maisie's lien is imputed to Isabella although Bernard's reason for failing to tell Isabella about the lien is his fear that, if he does, he will lose his commission because Isabella will refuse to purchase the property from Henry. ${ }^{48}$ Bernard has still accomplished Isabella's objective, acquiring property for her museum, albeit under circumstances that Isabella may well have reason to regret. Moreover, Bernard's reticence is a predictable consequence of the incentive structure created by his agreement with Isabella, which makes his commission dependent on consummating a transaction.

In contrast, suppose Bernard's reticence occurs because Henry bribes him not to reveal the fact of Maisie's lien to Isabella. ${ }^{49}$ Isabella is not charged with Bernard's knowledge. Bernard's failure to disclose the lien to Isabella is a consequence of a third party's inducement to Bernard to breach the duty he owes Isabella and not a consequence of the incentives and instructions implicit in the relationship between Isabella and Bernard. ${ }^{50}$ However, Bernard's knowledge may be imputed to Isabella when Bernard's actions have the effect of defrauding a third party who reasonably believes Bernard to be authorized, as when Bernard induces Junius to buy Isabella's painting by misrepresenting it to be a Vermeer. It is not a defense to Isabella that Ber-

law, with the intention of affecting the legal rights and duties of the notifier in relation to rights and duties of persons to whom the notification is given.

Restatement (THIRD) OF AgENCY § 5.01(1) (Tentative Draft No. 3, 2002). A notification given to an agent is effective against the principal if the agent had actual or apparent authority to receive the notification, unless the person who receives the notification knows or has reason to know that the agent is acting adversely to the principal. $I d$. $\$ 5.02(1)$.

47. See MECHEM, supra note 34, at 1411 ("It is not enough to prevent the application of the general rule [of imputation] that an agent to whom notice comes which would otherwise be imputed, shall, however wickedly or fraudulently, fail to communicate it to his principal.").

48. See Restatement (SECOND) OF AGENCY § 282 illus. 4 (1958) (providing a similar example with alternative terms).

49. See id. $\$ 282$ illus. 5 (providing a similar example with alternative terms).

50. If Maisie argues that Isabella should be charged with Bernard's knowledge because Isabella benefited from Bernard's action, Isabella may rely on the fact that, at the time of her purchase of the property from Henry, she paid value in good faith. See id. $\S 282 \mathrm{cmt}$. j. 
nard made the misrepresentation with motives antagonistic to her interests, perhaps because Bernard has formed an alliance with the forger that will reward Bernard, separate from his relationship with Isabella as her agent. ${ }^{51}$ Independently, Isabella will be charged with Bernard's knowledge if she retains the benefit of his conduct, knowing the facts. ${ }^{52}$

One might wonder why an agent's knowledge should be imputed to a principal when the question surfaces in an action brought by a third party alleging fraud but not when a third party challenges the circumstances under which a principal acquired property from someone else. When the agent has acquired the knowledge extramurally or prior to the agency relationship, most U.S. cases-unlike English precedents-do not draw this distinction, as discussed above. ${ }^{53}$ The question is whether this distinction is any more compelling when the agent acts adversely to the principal. If an agent acts adversely to a principal when the agent represents the principal in conducting a transaction with a third party that defrauds the third party, the agent's fraud is imputed to the principal on the basis that the principal chose to conduct the transaction with the agent as a representative and manifested to the third party that the agent had authority. This outcome sacrifices the innocent principal in the interest of protecting the third party with whom the agent dealt on the principal's behalf. However, the principal chose to deal through an agent, chose the agent, and led the third party to believe that the agent had authority. The third party's injury stems from an interaction with an agent apparently conducted on behalf of the principal. In contrast, when the plaintiff is not a third party with whom the agent has transacted on the principal's behalf, the plaintiff's injury or grievance is not linked to such an interaction. The agent's adverse interest places the agent beyond the consequences fairly to be ascribed to the position of control over the agent.

\section{TRADITIONAL JUSTIFICATIONS FOR IMPUTATION}

Conventionally, imputation is justified on two bases that differ in intellectual style as well as implications. First, it is said that imputa-

51. See id. cmt. f ("[A] principal may be liable for the fraud of an agent who is acting entirely for his own purposes but who, to the defrauded party, is apparently acting for the principal.").

52. See id. cmt. h ("This rule applies not only where the agent purports to act as agent in obtaining the benefit for his principal, but also where he commits a fraud independently.").

53. See supra notes $28-38$ and accompanying text. 
tion can be justified on the basis of an identity that is assumed to exist between principal and agent; a principal is charged with an agent's knowledge because principal and agent should be treated as sharing the same legal identity or personality. ${ }^{54}$ A pragmatic supplement to the formal argument from identity is that a principal should not, by using an agent, be advantaged in position compared with the consequences for the principal had the principal acted personally rather than through an agent. ${ }^{55}$ Grounding agency doctrines on an identity between principal and agent had an influential scholarly proponent, Oliver Wendell Holmes, $\mathrm{Jr}^{56}{ }^{56}$ Second, imputation is justified on the basis that if an agent knows a fact and is under a duty to relay it to the

54. See, e.g., Stump v. Ind. Equip. Co., 601 N.E.2d 398, 403 (Ind. Ct. App. 1992) ("Imputed knowledge is a tenet of agency law, and is based on an underlying legal fiction of agency-the identity of principal and agent when the agent is engaged in the principal's business.").

55. Watts, supra note 46, at 305 ("[A] perverse incentive to conduct business through agents rather than personally would be created were principals permitted to hide behind their agents' failures to communicate."). There are bases for this argument apart from an identification between agent and principal. For example, it is possible to focus on whether an act by the knowledgeable agent is a requisite to a tie, most typically a transaction, between the principal and the third party whose legal relations with the principal are at issue. See Peter Watts, The Company's Alter Ego-a Parvenu and Impostor in Private Law, N.Z. L. Rev. 137, 142-43 (2000).

56. On identification as the underlying basis for agency doctrine, see Oliver Wendell Holmes, Jr., Agency I, 4 HARV. L. REV. 345, 350 (1891). Holmes based his articles on lectures he gave on agency "at the Law School of Harvard College" and printed them without substantial revision several years later. See id. at 345. Holmes also discussed identification in The Common Law:

This notion of a fictitious unity of person has been pronounced a darkening of counsel in a recent useful work. But it receives the sanction of Sir Henry Maine, and I believe that it must stand as expressing an important aspect of the law, if, as I have tried to show, there is no adequate and complete explanation of the modern law, except by the survival in practice of rules which lost their true meaning when the objects of them ceased to be slaves. There is no trouble in understanding what is meant by saying that a slave has no legal standing, but is absorbed in the family which his master represents before the law.

Oliver Wendell Holmes, JR., The Common Law 183 (Mark DeWolfe Howe ed., Harvard Univ. Press 1963) (1881). Holmes's account does not address the duties an agent owes a principal.

As it happens, Holmes did not think agency had much intellectual substance as a body of doctrine. He characterized agency doctrine as the simple-minded result of combining the fiction of identity between principal and agent with common sense. Oliver Wendell Holmes, Jr., Agency II, 5 HARV. L. REV. 1, 14 (1892). Holmes closed this article with the pessimistic conclusion that it was not possible to resolve the outcomes of agency cases "into mere applications of general and accepted principles." See id. at 23. In contrast, the Reporter who completed the first and second Restatement of Agency began an article on the optimistic note that

I believe that Justice Holmes overestimates the effect of the fictions. On the contrary I

believe that the results reached by the courts can be explained without using legal pre-

sumptions as axioms and that individual cases may be tested by the use of judicial sense (rather than common sense) and the needs of commerce. On the whole the interests concerned have been well protected ....

Warren A. Seavey, The Rationale of Agency, 29 YALE L.J. 859, 859 (1920). 
principal, it can be assumed that the agent has fulfilled that duty. ${ }^{57}$ Characterizing this presumption as the basis for imputation also had a prominent champion, Joseph Story. ${ }^{58}$

Both justifications have strengths. It is appealing to base imputation on an identification between principal and agent because an agent's actions bind the principal-are treated as the acts of the principal-when the agent acts with actual or apparent authority. A principal's agents link the principal to the external world though the facts they learn about it, as well as through their actions. However, this justification has significant limits. It does not reflect the fact that principal and agent retain separate legal personalities. Each owes duties to the other and to third parties with whom the agent interacts on the principal's behalf.

Additionally, less than all of an agent's knowledge is imputed to the principal. As explained above, a principal is not charged with the knowledge of an agent who acts adversely to the principal, nor with

57. See, e.g., Apollo Fuel Oil v. United States, 195 F.3d 74, 76-77 (2d Cir. 1999) (applying the principle that, "[i]n general, when an agent is employed to perform certain duties for his principal and acquires knowledge material to those duties, the agent's knowledge is imputed to the principal," in finding a strong inference that whoever introduced red-dyed diesel fuel into the tank of a truck did so to benefit the corporation by enabling it to evade an excise tax payable on clear fuel used for transportation); Triple A Mgmt. Co. v. Frisone, 81 Cal. Rptr. 2d 669, 678-79 (Cal. Ct. App. 1999) (acknowledging that the basis for imputing an agent's knowledge to the principal "is that the agent has a legal duty to disclose information obtained in the course of the agency and material to the subject matter of the agency, and the agent will be presumed to have fulfilled this duty").

58. See STORY, supra note $27, \S 140$ :

$[\mathrm{N}]$ otice of facts to an agent is constructive notice thereof to the principal himself, where it arises from, or is at the time connected with, the subject-matter of his agency; for, upon general principles of public policy, it is presumed that the agent has communicated such facts to the principal; and if he has not, still the principal, having intrusted the agent with the particular business, the other party has a right to deem his acts and knowledge obligatory upon the principal; otherwise, the neglect of the agent, whether designed or undesigned, might operate most injuriously to the rights and interests of such party.

The first edition of Story's treatise was published in 1839 .

Interestingly, the eighth edition of Story's treatise was revised by Nicholas St. John Green, an associate of Holmes's. See Louis MENAND, THE METAPHYsiCAL Club 201 (2001). Green, a law professor at Harvard like Holmes, was a critic of legal formalism and thought that all beliefs had a "purposive character-that knowledge is not a passive mirroring of the world, but an active means of making the world into the kind of world we want it to be." Id. at 223-25. In the Metaphysical Club, Holmes and Green joined conversational forces in the 1870s along pragmatist lines with William James, Chauncey Wright, C.S. Peirce, and others. See id. at 201-30.

Green left Harvard for Boston University, reportedly in disgust when legal formalism came to dominate the curriculum following the appointment of Christopher Columbus Langdell as Dean. Id. at 231. Nonetheless, Green's work on Story's treatise does not indicate any disagreement with the fiction of imputation, including downward imputation of a principal's knowledge to an agent. See STORY, supra. 
the knowledge of an agent who owes another party a duty of confidentiality. That there are limits on the scope of imputation is inconsistent with treating identification between principal and agent as the underlying justification for imputation. A further inconsistency is that imputation is not a two-way doctrine because notice of facts known to a principal is not imputed to the agent. If, for example, Isabella knows that the painting in the second illustration is a forgery but Bernard does not know this, Isabella's knowledge is not imputed to Bernard. The one-way direction of imputation is not consistent with identification between principal and agent.

To be sure, a more nuanced account of identity can overcome some of these objections. Some forms of identity involve constitutive relationships between parts and a whole. By way of analogy, a basketball team scores whenever one of its members makes a basket, but we wouldn't say that whenever the team scores, any particular member does. Thus, the one-way direction of imputation isn't fatal to grounding imputation in an identification between principal and agent. Moreover, to say that there is an identity does not necessitate that the identity hold true for all purposes and all circumstances; after all, the agency relationship between Bernard and Isabella is itself limited in scope. The adverse-interest exception to imputation could then be rationalized as applying to situations in which an identity between principal and agent does not hold.

However, even with this modification, positing an identification between principal and agent does not quite capture the distinction drawn by the cases between situations in which an agent deals with the third party whose legal relations are at issue, as opposed to situations in which there is no such dealing. When Bernard sells the forged painting to Junius, having allied his interests with those of the forger, as between Junius and Isabella, Isabella is charged with Bernard's knowledge of the forgery. When Bernard buys property from Henry knowing of Maisie's unrecorded lien but does not tell Isabella about the lien because Henry bribes him to remain silent, as between Maisie and Isabella, Isabella is not charged with Bernard's knowledge of the lien. Perhaps for the purposes that imputation serves, the identification between Bernard and Isabella is inseverable when Bernard reasonably appears to the third party with whom he deals, and whose legal relations with Isabella are at issue, to be dealing on Isabella's behalf. This explanation looks beyond the postulate of identification to its purpose in a given context. 
Most contemporary cases, in contrast, tie imputation to the duties an agent owes a principal, stressing the agent's duty to transmit material facts to the principal. The chief attraction of this justification is that it is reasonable to believe that, in most cases, agents fulfill this duty, and often have done so even when in retrospect principal or agent claims otherwise. It is also reasonable to assume that it will be difficult in many instances for a third party to prove that an agent transmitted material information to the principal. However, justifying imputation on the basis of an agent's duty to a principal does not match well with significant aspects of well-settled doctrine. It is not a defense to a principal that an agent breached the agent's duty to transmit relevant information, even when the principal can establish that the agent withheld the information. Moreover, the U.S. cases charge a principal with an agent's material information whether or not the agent owed the principal a duty when the agent acquired the information.

Most tellingly, a principal is charged with an agent's knowledge of material facts even when the agent's failure to transmit the facts to the principal is consistent with instructions that the principal has given the agent. That is, if a fact is material to a principal's legal relations with a third party, the principal cannot defeat imputation on the basis that the agent complied with the principal's instructions in withholding the fact from the principal. Thus, an agent's duty to a principal does not fully explain why the agent's knowledge is imputed to the principal.

\section{ALTERNATIVE JUSTIFICATIONS}

It is more promising to treat imputation as a recognition of the fact that, when an agent interacts with third parties on behalf of a principal, the internal relationship between principal and agent shapes many dimensions of the agent's interaction with the third party. A principal has the power to select its agents and, in various ways, to exercise control over them. A principal's position enables the principal to furnish agents with instructions and incentives with the objective of guiding their conduct. This includes prescribing routines for how agents should handle information, as well as determining how best to reward agents who transmit material information.

As noted above, in most cases involving imputation, what is known to the agent is not favorable to the principal's legal position vis-à-vis a third party if the principal also knows the fact. Imputation responds to the evident temptation for agents to be reticent in sharing 
"bad facts" with their principals. An agent may be reticent about such a fact for many reasons, including the agent's belief that the principal would prefer not to know the fact. An agent's relationship with the principal provides many channels for the principal so to inform the agent, both explicitly and implicitly. Additionally, by setting an incentive structure for an agent, the principal may make it more likely that the agent will not reveal "bad facts" to the principal, as when the agent fears the principal will not conclude a transaction if the principal knows the facts and the agent's right to compensation depends on whether a transaction is consummated.

It is also possible that a principal may find it tempting to either embrace or disavow an agent, depending on how the agent's interaction with a third party actually turns out. For example, as the seller of a painting purported to be a Vermeer, Isabella will benefit if Junius does not learn that painting is a forgery, whether or not Isabella actually knows or suspects the truth. She may anticipate that benefit in how she deals with Bernard as her agent, for example by failing to encourage Bernard to be candid with prospective purchasers and by rewarding Bernard on the basis of the amount of sale proceeds he generates. Isabella and Bernard may also benefit if Junius's discovery of the truth is delayed. If (and when) Junius learns about the forgery, Isabella would, of course, prefer to distance herself from Bernard and the guilty knowledge that only he demonstrably has.

Imputation has the effect of denying principals an opportunity to deal with third parties on the basis that "heads I win, tails you lose," as determined by a principal after-the-fact of transactions entered into by an agent. This is consistent with a broad theme in agency doctrine. Across the board, agency doctrine tends to cut off a principal's ability to look after-the-fact at the consequences of an agent's interaction with a third party and determine then whether to be bound by what the agent has done. If Bernard buys a painting for Isabella, and he had actual or apparent authority to do so, Isabella cannot later avoid the purchase on the basis that Bernard made a poor choice. Agency doctrine forecloses Isabella's ability to argue that Bernard's power to bind her encompassed only those contracts that she, after the fact, finds advantageous. Isabella may argue that she extended authority to Bernard on such limited terms, but if she led third parties with whom Bernard dealt to believe that he acted with unqualified authority, Isabella will be bound on the basis of Bernard's apparent authority. 
In contrast, in the narrow run of cases in which an agent's knowledge is not imputed to the principal on the basis that the agent acted adversely to the principal, the risk of explicit or implicit collusion between agent and principal is missing. Likewise missing is any opportunity for the principal to speculate at the third party's expense. The agent's actions place the agent outside the control structures put in place by the principal, just as an agent is outside them when the agent deals with the principal as an adverse party.

Imputation may also be justified on the basis of its impact on behavior. It creates strong incentives for principals to select, train, and monitor agents carefully, and to design effective systems for handling and reporting information. Imputation also reduces a principal's incentives to deploy agents as shields against the legal consequences of information that a principal would prefer not to know. This is so because, from a principal's standpoint, it is preferable that an agent transmit "bad facts" so that the principal may determine how to react, as opposed to proceeding with a transaction in the absence of actual knowledge. Actually knowing the facts, a principal might decide to exit from a transaction, might negotiate for a different price, or might otherwise negotiate different terms. Imputation treats a principal as if the principal knew what the agent knew; if in fact the agent did not disclose material facts to the principal, the transaction might well be on terms that an informed principal would not have chosen, taking into account the legal consequences that follow from imputation.

The invariant quality of imputation may lead to results that seem unfair to a principal who has taken all reasonable measures-or even adopted measures beyond those most principals would adopt-in selecting and monitoring its agents. But this quality makes imputation doctrine simpler to apply than more nuanced fault-based alternatives would prove in practice. Its invariant quality is also consistent with basing imputation to some extent or in some fashion on an identification between agent and principal. That is, if for some purposes the agent is deemed to be the principal, it is hard to justify a lessening in the consequences of that identity when it is present.

Although the illustrations in this Essay have focused on simple relationships among agents and principals who are individual people, the justifications advanced for imputation have equal if not heightened validity when a principal is an organization. Imputing its agents' knowledge of material facts to an organization reduces the temptation for those who control the organization to structure it so that knowledge of bad facts is isolated to agents who are not otherwise 
implicated in the organization's dealings with a third party. ${ }^{59}$ Like the Circumlocution Office in Little Dorrit ${ }^{60}$ the result could be a repository for an organization's "bad facts" that would serve to deflect the organization's accountability to those with whom its other agents deal. ${ }^{61}$

\section{CONCLUSION}

Agency has not enjoyed much fashion within the legal academy in recent years. Many factors no doubt contribute to its unfashionable status, including its decline as a freestanding subject for law school instruction. ${ }^{62}$ Agency is also not much of a focus for specialization

59. In many organizations, "an almost natural screening of bad news takes place" to insulate those at the top from the actual knowledge to which law and society more broadly assign blame. MARK BOVENS, THE QUEST FOR RESPONSIBILITY: ACCOUNTABILITY AND CITIZENSHIP IN COMPLEX ORGANIZATIONS 79 (1998).

60. Charles Dickens, LitTle Dorrit (Penguin Books 1998) (1857). As described in Chapter 10 (entitled "Containing the whole Science of Government"), the Circumlocution Office was the point of referral throughout the government when "[w]hatever was required to be done, the Circumlocution Office was beforehand with all the public departments in the art of perceiving-HOW NOT TO DO IT." Id. at 110. The breadth of its influence was extensive:

Numbers of people were lost in the Circumlocution Office. Unfortunates with wrongs, or with projects for the general welfare ... who in slow lapse of time and agony had passed safely through other public departments ... got referred to the Circumlocution Office, and never reappeared in the light of day.

$I d$. at 112. When challenged, the Circumlocution Office could count on loyal Parliamentary defenders, with the result that "the Circumlocution Office was always voted immaculate, by an accommodating majority." Id.

61. On the imputed collective knowledge of an organization, see Gutter v. E.I. DuPont de Nemours, 124 F. Supp. 2d 1291, 1309 (S.D. Fla. 2000):

Courts impose constructive knowledge upon a principal to avoid the injustice which would result if the principal could have an agent conduct business for him and at the same time shield himself from the consequences that would ensue from knowledge of conditions or notice of the rights and interests of others had the principal transacted his own business in person.

62. Some of this decline is perhaps attributable to generational changes. Many law school curricula included a mandatory course in agency through the mid-to-late 1960s. However, as those who taught the subject retired from classroom service, the subject either lost its mandatory status, or those in the next generation assigned to teach it did not protest when curricular changes eliminated the agency course. For the history at Harvard Law School, see LouIS Loss, ANECDOTES OF A SECURITIES LAWYER 18-20 (1995). When Professor Loss joined the Harvard faculty in 1952, agency was a mandatory first-year course, taught in three or four sections by a cohort of eight professors that included Warren A. Seavey, the Reporter for the first and second Restatement of Agency. Id. at 18-19. Seavey retired from teaching the next year. Id. at 19. In the 1962-63 academic year, the faculty voted unanimously to abolish Agency as a separate course on the stated assumption that the material would be covered in other courses, such as Corporations. $I d$. at 20. Professor Loss reports that

[n]one of us wanted to stand in the way of progress-although ... I am not at all sure that the various offerings that were invented to fill the Agency slot have in fact improved the teaching program in general. The difference is that several of us who had 
within the legal profession; although its doctrinal tenets reach broadly, agency is not likely to fill the plate of a lawyer's work however much agency doctrines may matter on particular points. That agency does not parallel specialization within the legal profession may also help explain its low visibility within the academy.

Many doctrines within agency also have qualities that place them out of sync with developments in other areas of the law and legal theory. Basic agency doctrines are not fault-based; the legal consequences of an agent's actions are attributable to a principal even when the principal was without fault in selecting or monitoring the agent. Basic agency doctrines also operate on an all-or-nothing basis; either the legal consequences of an agent's actions are attributable to the principal, or they are not. If an agent acts with actual or apparent authority on behalf of a principal, the principal is bound by what the agent did, even when the principal did not realize any benefit as a result. Thus, agency doctrines may strike some as unduly severe and unmodulated by concern for the specifics of individual cases. Some may be troubled by the conclusion that an agent may have acted "on behalf of" a principal when, in fact, the principal did not benefit as a consequence of the agent's actions.

Imputation, as examined in this essay, is representative of agency doctrines more generally. An agent's knowledge of material facts is, subject to a few exceptions, imputed to the principal even when, in demonstrable fact, the principal was blameless. This is so even when the principal is an organization including constituents who are blameless and who were not in a position to control the agent. A principal may not defeat imputation of an agent's knowledge on the basis that by withholding information, the agent breached a duty owed to the principal or, in some other respect, did not benefit the principal.

However unfashionable its intellectual style, imputation is crucial to the legal accountability of organizations and of principals more generally. Imputation reflects the insight that how an agent handles information often reflects the agent's understanding with the principal and the agent's expectations about whether the principal wishes the agent to be forthcoming or reticent when the agent knows information material to the principal's legal relations. Systematically, an agent may err on the side of reticence when it would be detrimental

taught Agency under the private tutelage (at least in my case) of the great master voted for abolition with a tear rather than a cheer. 
to the principal to learn what the agent knows. If a principal can evade the legal consequences associated with knowledge, the principal can interact with third parties through agents in a manner that is calibrated to distance itself from knowledge of facts that the principal would prefer not to know. This increases the risk that a principal will evade the consequences of its agents' actions by assessing whether they are advantageous or not for the principal, after-the-fact of action taken by agents. Imputation guards against this risk. 